\section{BIBECHANA}

A Multidisciplinary Journal of Science, Technology and Mathematics

ISSN 2091-0762 (online)

Journal homepage: http://nepjol.info/index.php/BIBICHANA

\section{BIBECHANA}

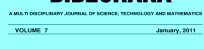

volum

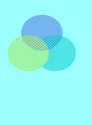

\title{
Waste management
}

\section{Devesh Pradhan*}

Dept. of Chemistry, Bhanu M.H.S.S. Biratnagar, Nepal

Article History: Received 29 October 2010; Revised 25 November 2010; Accepted 2 December 2010

\begin{abstract}
Waste management has become very challenging in our society. Different types of wastes which are produced in our society have been investigated. Special attention has been given in the management methods of waste.
\end{abstract}

\section{Keywords: Industrial waste, Domestic waste, Composting, Recycling}

\section{Introduction}

Wastes are produced by all living things - exerted by an organism or thrown away by society because they are no longer useful. But the make up of waste means that once discarded by one body its constituents may become useful to another. In the natural world, a waste produced by an animal that urinates, is disposing of waste products its body does not need, but the water and nutrient can become resources for other organisms. Similarly, sewage from a town or municipality can be used by bacteria (microbe) which break it down in a river, for example, an old shirt discarded by one person might be worn by another, often poorer individual. The term waste is therefore a label determined by ecology, economics or culture.

Much of the waste produced by human society is natural although we have created products not found in natural world, such as CFCs and plastics which can become wastes. The use of resources, by people, and hence production of waste has accelerated in the period since the Industrial revolution, and this fact combined with the growing number of people on the planet has created increasing volumes of waste that need to be disposed off. This disposal requires are careful management since too much waste disposed off in a certain place at a certain time can contaminate or pollute the environment, creating a hazard to the health, safety or welfare of living things.

The principal objective of waste management is to control, collect, treat, utilize and dispose off the wastes in an economical manner consistent with the protection of public health.

\section{Types of wastes}

Wastes have different forms: solid, liquid, gas or energy in the form of heat or noise. The sources of wastes are following:

\subsection{Domestic and municipal wastes}

\footnotetext{
* Address for Correspondence: Devesh Pradhan, Dept. of Chemistry, Bhanu Memorial Higher Secondary School, Biratnagar-14, Morang. Email: deveshsmail@yahoo.com
} 
These include wastes (garbage and rubbish) from households offices, hotels, markets, etc. and also the refuse such as street sweepings, dirt, leaves, etc. The term 'garbage' is generally used to denote bio-degradable food wastes. The term 'rubbish' is used to denote nonbio-degradable.

\subsection{Agricultural wastes}

These wastes result from farm, feed lots and live stock yards. The agricultural waste include paddy husk, baggage from sugar cane, tobacco and corn residue, slaughter house wastes, manure

\subsection{Industrial wastes}

These include non process wastes such as packing wastes, raw material wastes and process wastes which depend upon the type of product being manufactured such as tannery wastes, weaving and dyeing wastes, food processing wastes, plastic wastes, rubber wastes, metal scraps, etc. from the respective industrial establishment.

\subsection{Mining and construction wastes}

These include the waste produced in coal mining, gold mining, copper mining, china clay mining, etc.

\subsection{Special wastes}

The wastes that are toxic to humans, plants or animals, are inflammable, corrosive,exclosive or radioactive. Such hazardous wastes include acids and alkalis, heavy metals, oils, solvents, pesticides, enzymes, antibiotics and various hospital wastes.

\section{Disposal of waste}

All wastes are disposal off into the environment, but some enter the environment in a more controlled manner than others. Wastes produced from the combustion of fuel by vehicles are emitted directly into the atmosphere, while domestic sewage wastes are often collected by municipal authorities and disposed off into specific locations such as a river or ocean. The three major reservoirs (air, river \& ocean) are publicly owned and this common ownership has facilitated unregulated emission of wastes. In many countries, however, the gradation of these common property resources by wastes have spawned numerous controls on their emission. Wastes that are actively managed and a wide range of management options are available. The most commonly used options are:

(a) Sanitary land fills or controlled tipping

(b) Thermal process (e.g. incineration and pyrolysis)

(c) Composting

(d) Recycle and re-use

(f) Waste prevention, cleaner production

\subsection{Sanitary land fills}

Land filling is the most common and economic method of solid waste disposal in many countries. The 'municipal dump' generally used to be in low-lying area near a water course. This unsanitary dumping of the waste used to result in water pollution, bad odours. Blowing papers, rats or fermentation bacteria can generate methane and cause a fire hazard.

These problems were mostly reduced by burial of waste after compacting the waste in layers and covering it with soil at the end of the disposal of the waste every day. This method of land fill is known as 'sanitary land fill'. Although compacting and covering still continue to be basic operations today, several further improvements in the process have taken place during recent years. These include careful and scientific site selection, controlled deposition, better 
methods of compaction, reduced cover, leachate collection to avoid water pollution and site monitoring to ensure environmental protection.

In sanitary land fill, complex organic wastes are slowly decomposed by the soil microorganisms. The aerobic bacteria decompose the organic solid waste by using whatever oxygen is present inside the land fill. Then, decomposition by the anaerobic begins and this accounts for the degradation of most of the solid waste present in the landfill. The water soluble organic acids generated in this process enters the water media and diffuses through the landfill soil. The bacteria present in the soil aerobically metabolize these organic acids into $\mathrm{CO}_{2}$ and water.

In order to control the contamination of ground water by the leachate (contaminated liquid having high organic content, soluble salts and other constituents) certain regulations are prescribed for sanitary landfills. These include mandatory minimum distance of the location of landfills above the ground water level, minimum distance from the nearest point of water use of soil of low permeability, preventing the build up of the leachate within the landfill, drainage and ground water depth and movement etc., supplementary measures such as clay covers for the landfill, leachate collection, removal and treatment facility, installation of monitoring system are also suggested to ensure that the buried refuse remains as dry as possible and the leachate do not reach the ground water. In spite of these precautions, if some leakage of the leachate still occurs, the soil serves as an additional barrier by mechanism such as filtration, absorption, precipitation and biological activity.

If properly designed and managed, landfill sites may do little harm to the environment and can eventually provide a surface for such land uses as playing fields or reforestation, although not usually for heavy structures such as housing.

\subsection{Thermal process}

The important thermal processes used in solid waste treatment are incineration and pyrolysis.

\subsubsection{Incineration}

In this process, the solid organic wastes are subjected to combustion so as to covert them into combustible residue and gaseous products. Incineration is increasingly used in many countries to reduce the bulk of wastes and to break down hazardous compounds, so rendering them less dangerous. The incineration process is considered when suitable site for land filling is not available within the economic distances from the sources of solid wastes.

Incinerators do, however, release harmful emissions into the atmosphere, such as particulate matter, heavy metals and trace organics. Such emissions can be limited with a range of approaches, such as improved combustion techniques, sorting of wastes prior to incineration and by fitting pollution control devices. Ash produced in incinerators is commonly buried in landfills, although some attempts have been made to use this ash as a component of building materials.

\subsubsection{Pyrolysis}

The chemical constituents of some organic wastes can be recovered by destructive distillation (or pyrolysis) of solid waste. In this process, the combustible constituents of the solid waste are heated in a special retort retort like chamber known as pyrolysis reactor at 600 to $1000^{\circ} \mathrm{C}$ in a low oxygen or an oxygen free environment. This is an endothermic process and thus differs from the conventional incineration. Pyrolysis of the solid yields the following components.

(a) Tan or oil containing methanol, acetone, acetic acid etc (b) Gaseous phase containing $\mathrm{H}_{2}, \mathrm{CH}_{4}, \mathrm{CO}, \mathrm{CO}_{2}$ etc (c) Solid phase containing pure carbon char and inert materials like glass, rock, metal, etc.,

The advantages of pyrolysis process include:

$\begin{array}{ll}\text { (a) Volume reduction by about } 90 \% & \text { (b) Possibility of handling potentially hazardous }\end{array}$ plastics, e.g. P.V.C. in a safe way (c) Absence of pollution problem. 


\subsection{Composting}

It may be carried out naturally under controlled condition or in mechanized composting plants. In natural system, the solid waste is placed on slow moving conveyor belts. Materials like glass, paper, metals are hand-picked and them the ferrous materials are removed by magnetic separation. The waste is then ground in hammer mills to the desired size range $(0.6$ to $2.5 \mathrm{~cm})$. Then it is mixed with nutrient source (e.g. sewage sludge, animal manure or night soil), filler (e.g. wood chips or ground corn cobs) and water (to provide 50\% moisture). This is known as waste preparation.

The mixture or waste preparation is placed in the windows for 4 to 6 weeks, while turning it once or twice a week. The waste is decomposed by thermophilic micro-organism during this period. The materials are then allowed to stabilize for other 2 to 5 weeks, the temperature falls, the colour darkens and a musty odour develops. This indicates completion of the process. The filler may then be removed and the remaining humus like material is used as soil conditioner. With mechanical systems, the composting time is reduced to half of that required in natural systems, because of continuous aeration and mixing.

In order to ensure quick and better marketing prospects, the product is sometimes upgraded by operations such as curing, grinding, and screening, pellestising and bagging.

\subsection{Recycling and reuse}

Realization of the economic value of certain wastes promotes reuse, recovery and recycling. In many developing countries, informal scavenging of municipal wastes from city dumps is widely practiced and the materials recovered are put to a variety of uses. It provides employment for individuals who otherwise would have none, particularly important in those countries where social security systems are inadequate or non-existent. Low cost buckets, charcoal stoves and lamps are all made from scavenged metals from city dumps and sold to people who live in squatter settlements in the city.

In the more developed countries such informal waste recovery was also common more than 100 years ago, but more formalized recycling schemes have now sprung up. These schemes are more advanced for metals and some other materials such as glass, paper and broken polythene and collection points for such solid wastes have become a familiar sight in many cities in recent years.

From the standpoint of energy conservation there is every justification for the recycling and reuse of ferrous metals, aluminium and some other non-ferrous metals because the mining of virgin material is energy intensive. As far as glass is concerned, it was found that the energy spent on reuse of old glass is more than that required to process new material. Hence energy saving can be realized only by reuse of the glass containers than to reprocess them.

Paper constitutes nearly $50 \%$ by weight of the solid wastes. Total recycling of paper has not been possible so far. Unrecoverable paper is generally disposed by

controlled incineration and the gaseous products obtained are $\mathrm{CO}_{2}$ and water vapour which are non-polluting. Paper has a high heat of combustion and hence is disposed by converting it to energy. Refuse derived fuel (RDF) can be used as supplementary fuel for use in boilers or in other combustion processes.

Recycling of plastics received considerable attention primarily because of ever increasing use of plastics and also because of their non-biodegradable nature. For a satisfactory recycling of plastics the following two requirements are to be taken into account:

(a) The plastic material should be made up of only on type, i.e. it should be homogeneous.

(b) The plastic scrap or waste should be collected from the consumer.

Recycling of plastics may be carried out in any of the following ways:

(a) Primary recycling where the same plastic product is manufactured again. 
(b) Secondary recycling where the material the material is reprocessed to a new product with different composition of inferior quality.

(c) Tertiary recycling where the plastic material is completely processed to a new form as in pyrolysis.

Another waste product that is commonly reused or recycled in many countries is waste water from urban areas. It is often diverted to cropland for irrigation. The water itself is a valuable resource and sewage contains plant nutrients (phosphorous and nitrogen).

In countries where sewage is treated, the sludge that remains after treatment is also reused as a fertilizer due to it's high nutrient content. About half of the sewage sludge produced in the UK and a third of that in Germany is reused in this way, but in these and other countries, further use is limited due to its high heavy metal (gold, platinum, and palladium) content. Hence, sewage sludge not used as fertilizer is disposed off by ocean dumping, dumping in landfill or incineration.

As population and industrialization continue to increase, however, and the treatment of water and sewage becomes more widely used in order to reduce the pollution impacts from untreated sewage outlet, so more sludge will need to be disposed off. An innovative approach to this increasing dilemma of disposal can turn a problem into a benefit by recovering the heavy metal from sewage and sludge. The global production of palladium from sewage and sludge could be of the same order of magnitude as that from mining production. The future disposal off sewage sludge should concentrate on the control of pollutants at source and extraction of metals, as approach which would yield numerous benefits, including.

(a) More wide spread use of sludge as fertilizer

(b) Revenue from metals extracted

(c) Conservation of geological metal resources

(d) Saving on expensive waste depository space

(e) Prevention of environmental impacts on terrestrial and marine ecosystem

\subsection{Waste prevention, cleaner production}

There is no doubt that the best way to manage waste is to prevent it at source whenever this is possible. On the other hand cleaner production is a preventive approach to environmental protection. Cleaner production is achieved by examining all phases of a product's life cycle, from raw material extraction to its ultimate disposal, and reducing the wastefulness of any particular phase. Cleaner production embodies the ideas both of environmental sustainability and of economic efficiency. In practice it involves improving the productivity of energy and material use to reduce consumption of resources and cut pollution per unit output. A number of companies go beyond legal requirements, however, and attempt to develop 'closed loop' proceeding cycles in which waste products are completely recycled and enter the environment to become pollutant.

\section{Conclusion}

This review presented here gives information about several sources and activities which produce waste in our society. These waste- producing sources and activities can not be completely controlled. So the waste management methods should be discovered. The existing waste management methods should be improved.

\section{References}

[1] www.enpho.org

[2] www.wateraid.org/nepal

[3] D. Pokhrel et al Municipal Solid Waste Management in Nepal: Practices and Challenges, Waste Management, Science Direct, 25 (2005) 555.

[4] www.wisegeek.com/ 